\title{
MENINGKATKAN MUTU DAN PROFESIONALISME GURU
}

\author{
DOLA RAHMA NANDA
}

\author{
dolarahmananda@gmail.com
}

\begin{abstract}
ABSTRAK
Dengan mengetahui permasalahan pendidikan yang ada diharapkan dapat dibuat suatu kebijakan yang sesuai untuk meningkatkan mutu dan profesionalisme guru. Pendidikan sebagai suatu sistem terbuka tidak lepas dari masalah, baik masalah mikro ataupun masalah makro. Berkaitan dengan permasalahan yang sering terjadi di Indonesia, guru dianggap sebagai sumber dari permasalahan tersebut, sehingga dengan mengidentifikasi permasalahan pendidikan kita mengetahui letak permasalahan yang sebenarnya dan berusaha untuk memberikan solusi dari permasalahan tersebut.
\end{abstract}

Kata Kunci: Mutu, Profesionalisme Guru

\section{LATARBELAKANG}

Pendidikan sebagai suatu sistem terbuka tidak lepas dari masalah, baik masalah mikro ataupun masalah makro. Masalah mikro, yaitu masalah yang timbul dalam komponen komponen yang terdapat dalam pendidikan itu sendiri sebagai suatu sistem, antara lain masalah kurikulum, masalah pendidikan, administrasi pendidikan dan sebagainya.

Masalah pendidikan di Indonesia jika ditinjau dari sisi kualitas Sumberdaya Manusia di Indonesia masih jauh bila dibandingkan dengan Negara lain. Berdasarkan data World Education Ranking yang diterbitkan Organisation for Economic Cooperation and Development (OECD, 2015), di posisi mana suatu negara maju dalam segi pendidikan. Organisasi ini menentukan peringkat negara mana yang terbaik dari segi membaca, matematika, dan ilmu pengetahuan.

Sejalan dengan kondisi peringkat pendidikan Indonesia dibandingkan negaranegara lain di dunia, banyak faktor yang menentukan keberhasilan dari peserta didik, mulai dari sarana dan prasarana sekolah, kondisi ekonomi orang tua, Peran Pendidik, lingkungan belajar, lingkungan keluarga, faktor psikis dari peserta didik dan masih banyak faktor yang lainnya. Dari sekian banyak faktor yang mempengaruhi keberhasilan peserta didik yang paling berperan adalah pendidik dalam hal ini adalah guru. 


\section{PEMBAHASAN}

permasalahan utama yang menjangkiti dunia pendidikan di Indonesia, yaitu: bagaimana seluruh masyarakat bisa memanfaatkan peluang pendidikan dan bagaimana pendidikan bisa menyiapkan siswa dalam hal kemampuan dan skill yang siap untuk bersaing di dunia kerja.

Ada empat faktor sebagai poin penting dalam kaitannya dengan permasalahan pokok Pendidikan di indonesia dan perlu segera untuk diselesaikan, yaitu: (1) Masalah pemerataan pendidikan, dimana isu ini berkaitan dengan sistem pendidikan seyogyanya menyiapkan peluang yang sangat besar bagi seluruh masyarakat agar dapat mengakses pendidikan, yang mana mampu menjadi tempat bagi keberlanjutan peningkatan SDM di Indonesia.(2)Mutu pendidikan sangatlah luas cakupannya, banyak yang hanya melihat dari kualitas luarannya. Apabila kita sadari proses belajar yang baik akan menghasilkan luaran yang baik pula, maka jika proses belajarnya kurang baik maka mutu hasil yang diharapkan akan kurang baik juga. Jika terjadi pembelajaran yang kurang optimal hal ini mengakibatkan nilai tes yang baik, sehingga bisa dikatakan hasil belajar itu semu.(3)Membahas tentang efisiensi dalam sistem pendidikan dimana erat kaitannya dengan pemanfaatan segala kekuatan yang dimiliki agar tercapai misi yang rencanakan. Apabila dalam penggunaanya hemat dan cermat maka bisa disimpulkan bahwa tingkat efisiensinya tinggi. Tetapi apabila terjadi sebaliknya, maka efisiensinya dikatakan kurang.(4)Masalah relevansi berkaitan erat dengan sistem pendidikan dan pembangunan secara umum serta kepentingan perseorangan, masyarakat secara jangka pendek maupun jangka panjang. Masalah ini membahas seberapa dalam sistem pendidikan bisa menciptakan karya yang cocok dengan keberlangsungan suatu proses pembangunan. Apabila sistem pendidikan menciptakan output yang dibutuhkan di semua lini pembanguanan, bisa berhubungan langsung ataupun tidak dengan permintaan dunia kerja maka kualitas luaran yang dipersyaratkan oleh lapangan kerja, maka tingkat kebutuhan tersebut sesuai dengan yang dibangun oleh lembaga.

Solusi yang bisa ditawarkan untuk meningkatkan mutu pendidik diantaranya: (1) seleksi yang ketat untuk penerimaan mahasiswa calon pendidik; (2) Pengembangan keteramilan tenaga pendidik melalui pelatihan-pelatihan; (3) penyempurnaan kurikulum yang materinya disesuaikan dengan muatan lokal di daerah setempat; (4) pengembangan sarana dan prasaran yang dapat menciptakan suasana belajar yang nyaman; (5) penyempurnaan administrasi sekolah sehingga dapat efisiensi anggaran; (6) pengorganisasian dalam rangka untuk menjaga kualitas penyelenggara pendidikan perlu ditetapkan dengan didukung oleh lembaga yang sudah diberi wewenang dalam menjamin mutu diantaranya Lembaga Penjamin Mutu Pendidikan, dari Badan Akreditasi Nasional Sekolah Madrasah (BAN-SM) maupun dari lembaga independen.

Paradigma sekolah sudah banyak berkembang dari dulu hingga saat ini. Dulu sebuah sekolah sudah bisa menjalankan kegiatan pembelajaran apabila terdapat siswa, guru dan ruangan untuk proses pembelajaran dengan peralatan dan sarpras seadanya. Guru juga dijadikan sebagai sumber utama. la dijadikan sebagai sumber 
ilmu. Tugasnya mengalirkan pengetahuan ke siswa. Hal tersebut untuk saat ini sudah sudah tidak relevan dimana tugas guru sudah tidak menjadi penceramah yang harus selalu berdiri di depan siswa dan menjelasakan materi semua. Melainkan peran guru sudah berubah dimana tugsa guru menjadi fasilitator, mediator motivator guna menumbuhkan kreativitas dan daya imajinasi yang bagus siswa.

\section{KESIMPULAN}

Berdasarkan uraian di atas dapat disimpulkan bahwa ada empat poin yang berkaitan dengan identifikasi permasalahan pendidikan yaitu: masalah pemerataan pendidikan, masalah kualitas pendidikan, masalah efisiensi dan masalah relvansi

Dengan mengetahui permasalahan pendidikan tersebut ada beberapa solusi yang meningkatkan mutu dan profesinalisme guru yaitu: (1) seleksi penerimaan calon pendidik; (2) Pengembangan keteramilan tenaga pendidik; (3) penyempurnaan kurikulum; (4) pengembangan sarana dan prasaran; (5) penyempurnaan administrasi sekolah; (6) pengorganisasian dalam rangka untuk menjaga kualitas penyelenggara pendidikan.

\section{REFERENSI}

Kementerian Pendidikan dan Kebudayaan, Nilai UKG SMA Tahun 2015. http://ukg.kemdikbud.go.id

Idris, HZ. Pengantar Pendidikan 2. Jakarta: Gramedia Widiasarana, (1992).

Undang-Undang RI No. 14 Th. 2005 Tentang Guru dan Dosen

Undang-Undang RI No. 20 Th. 2003 Tentang Sistem Pendidikan Nasional 